\title{
Effects of Heavy Metal Contamination from an Abandoned Mine on Tomato Growth and Root-knot Nematode Development
}

\author{
Byeong-Yong Park ${ }^{1}$, Jae-Kook Lee ${ }^{1}$, Hee-Myong Ro ${ }^{2}$ and Young Ho Kim ${ }^{2 *}$ \\ ${ }^{1}$ Division of Crop Protection, National Academy of Agricultural Science, Suwon 441-707, Korea \\ ${ }^{2}$ Department of Agricultural Biotechnology and Research Institute of Agriculture and Life Sciences, Seoul National University, \\ Seoul 151-921, Korea
}

(Received on April 27, 2011; Revised on July 29, 2011; Accepted on August 1, 2011)

Physicochemical characteristics and heavy metal content of soils located along the drainage way of an abandoned mine at Busan, Korea $\left(35^{\circ} 31^{\prime} \mathrm{N}, 129^{\circ} 22^{\prime} \mathrm{E}\right)$ (contaminated soil; $\mathrm{CS})$ and uncontaminated soils (50$70 \mathrm{~m}$ apart from the drainage way) (NS) were examined. Growth of tomato plants (Solanum lycopersicom cv. Rutgers) in CS and NS, development of the root-knot nematode (Meloidogyne incognita) as root-knot gall formation on tomato plants, and non-parasitic nematode populations in soil were also examined. Growth of tomato plants, root-knot gall formation, and non-parasitic nematode populations were significantly reduced in CS with higher As content, lower $\mathrm{pH}$, higher electrical conductivity (EC), and lower available phosphate (av. $\mathrm{P}_{2} \mathrm{O}_{5}$ ) than in NS. None of the other physicochemical characters examined differed significantly between CS and NS (low and no significance) and were above or below the critical levels detrimental to plant growth and nematode development, suggesting that As may be the primary hazardous heavy metal in CS. The toxicity of As might be enhanced at low pH in CS because exchangeable forms of some heavy metals increase with the decrease of soil pH. The heavy metals, especially As, may have contributed to increasing $\mathrm{EC}$ and decreasing av. $\mathrm{P}_{2} \mathrm{O}_{5}$. Therefore, the effects of mine drainage contamination from the abandoned mine were derived primarily from contamination by heavy metals such as As. These may have been enhanced in toxicity (solubility) by the lowered pH, increased soil salinity (EC) and decreased av. $\mathrm{P}_{2} \mathrm{O}_{5}$. Our results suggest synergistic adverse effects on the plant and the nematode by decreasing osmotic potential and nutrient availability.

Keywords : gall formation, heavy metals, Solanum lycopersicum, Meloidogyne incognita, mine drainage

\footnotetext{
*Corresponding author.

Phone) +82-2-880-4675, FAX) +82-2-873-2317

E-mail)yhokim@snu.ac.kr
}

Abandoned mines are sources of heavy metals that contaminate nearby soil and water systems via mine drainage and debris containing a large quantity of heavy metals, which are neither decomposed to non-toxic compounds nor transformed into safe material (Adriano, 1986; McBride, 1994; Rajkumar et al., 2005). Heavy metal contamination affects soil health by inhibiting soil functioning due to decreases in microbial activity, soil enzymes, nitrogen fixation, and growth of microfloral communities such as fungi, algae, and photosynthetic bacteria (Mhatre and Pankhurst, 1997). Accumulation of heavy metals such as $\mathrm{Cu}, \mathrm{Pb}, \mathrm{Zn}$, and $\mathrm{As}$ in soil can lead to plant physiological disorders and even death, although damage from these heavy metals may not be very high (Holmgren et al., 1993; Vulava et al., 1997). For example, germination of pine seeds is reduced in proportion to the heavy metal content (Seo et al., 2006). Moreover, $\mathrm{Cd}$ and $\mathrm{Hg}$ accumulate in crop plants and are detrimental to human and animal health (Holmgren et al., 1993; Vulava et al., 1997).

Soil faunal communities such as nematodes, protozoa, and earthworms are also reduced in abundance and richness in soils contaminated with heavy metals (Mhatre and Pankhurst, 1997). In particular, all nematode trophic groups, including bacterivores, fungivores, predators, and plant parasites, are reduced in abundance and richness (Park, 2011). In soil ecosystems, a reduction in all nematodes other than plant parasites indicates a reduction in soil functioning and health, as non-parasitic nematodes play an important role in the soil ecosystem, contributing directly to nitrogen mineralization and biomass distribution and indirectly through grazing on decomposer microbes, secreting ammonium, and immobilizing nitrogen in live biomass (Beare, 1997; Ferris et al., 1998; Ingham et al., 1985; Neher, 2001). On the other hand, a reduction in plant parasitic nematodes due to heavy metal contamination implies an improved soil health, defined as the continued capacity of soil for biological productivity, plant health, and productivity (Doran et al., 1996).

Few studies have been conducted on the influence of 
heavy metals on soil functioning and plant health, especially in relation to diseases caused by plant-parasitic nematodes. The present study examined the effects of heavy metals on the growth of tomato and the development of the root-knot nematode, Meloidogyne incognita, using soils sampled from areas around an abandoned mine in Busan, Korea. The physicochemical characteristics of the soil (including heavy metal content) were analyzed, and tomato seedlings planted in this soil and plants inoculated with $M$. incognita were examined for growth and nematode disease development. Population changes in non-parasitic nematodes in the soil were also examined.

\section{Materials and Methods}

Soil sampling and analysis of soil characters. Soils were obtained from six experimental sites [three sites contaminated with mine drainage (CS: CS-1, CS-2, CS-3) located along the drainage way and three uncontaminated sites with mine drainage (NS: NS-1, NS-2, NS-3) (50-70 m apart from the drainage way) around an abandoned mine at

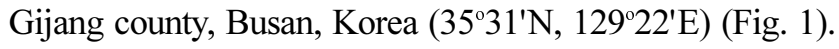
This mine was developed for copper and silver mining in 1930 but has been abandoned since 1980. Soil samples of about $1 \mathrm{~kg}$ were taken from each site, dried under shade for 2 weeks, and sieved through a $2.0-\mathrm{mm}$ aperture sieve

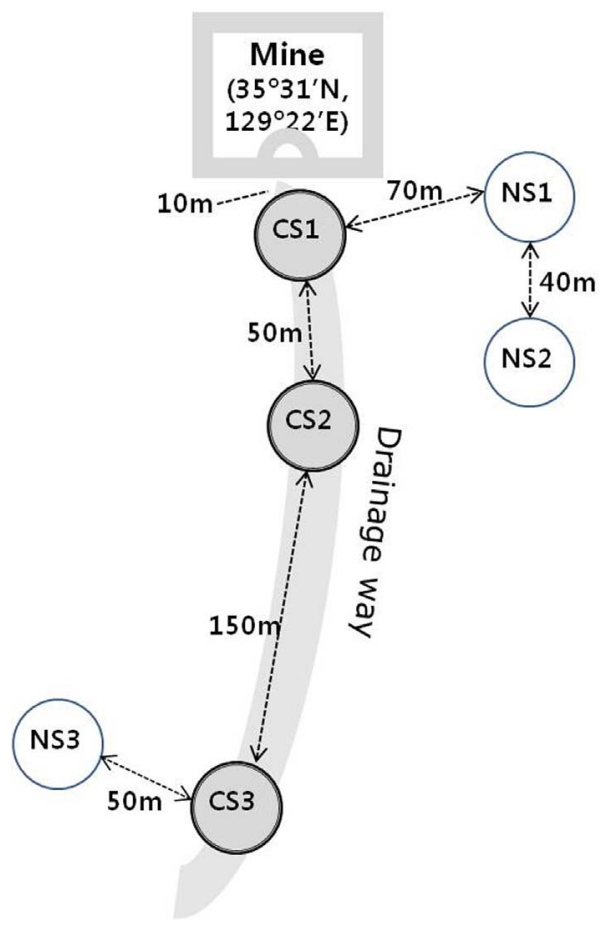

Fig. 1. Sampling sites of soils along the drainage way of an abandoned mine (contaminated soil; CS1, CS2 and CS3) located at Gijang county, Busan, Korea and uncontaminated sites (NS1, NS2 and NS3) 50-70 m apart from the drainage way. before analysis. Soil texture was determined by measuring the amount of clay, silt, and sand in a 10-g sample suspended in a soil dispersant (using a pipette) after removal of organic matter by boiling in $\mathrm{H}_{2} \mathrm{O}_{2}$ for 1 week, and of $\mathrm{Ca}$ using $\mathrm{HCl}$ (Klute, 1986). Following the methods described by the NIAST (2000), soil pH and electrical conductivity (EC) were analyzed using $\mathrm{pH}$ and $\mathrm{EC}$ meters, organic matter by the Tyurin method, total nitrogen (T-N) by the Kjeldahl method, available phosphate $\left(\mathrm{av} . \mathrm{P}_{2} \mathrm{O}_{5}\right)$ by the Lancaster method using a spectrophotometer, and $\mathrm{NO}_{3}-\mathrm{N}$ and $\mathrm{NH}_{4}-\mathrm{N}$ extracted in $2 \mathrm{M} \mathrm{KCl}$ using an automatic ion analyzer. Soluble cations $\left(\mathrm{Ca}^{2+}, \mathrm{Na}^{+}, \mathrm{K}^{+}\right.$, and $\left.\mathrm{Mg}^{2+}\right)$ were determined by flame photometry, and heavy metal content was determined by ICP atomic emission spectrophotometry using $10 \%$ soil solutions containing $0.1 \mathrm{~N} \mathrm{HCS}$ that were held in a glass flask at $30^{\circ} \mathrm{C}$ for $1 \mathrm{~h}$ and then filtered through Whatman No. 2 filter paper (MOE, 2005).

Plant growth and nematode development in soils from the abandoned mine. Tomato (Lycopersicon esculentum cv. Rutgers) seedlings (susceptible to the root-knot nematode) were planted and grown in sterilized vermiculite for 3 weeks and then transplanted into $12-\mathrm{cm}$-diameter clay pots each containing $650 \mathrm{~g}$ soil from the experimental sites. Sandy loam culture soil, with a texture similar to the experimental soils, was used as a control and inoculated with or without the root-knot nematode. Each plant was inoculated with 1,000 eggs of $M$. incognita obtained from greenhouse-grown tomato plants used for nematode multiplication. Each treatment was replicated five times. Pots were arranged in a randomized block design on a bench in a greenhouse at $25 \pm 2{ }^{\circ} \mathrm{C}$ and were watered daily to field capacity. About 8 weeks after nematode inoculation, plants were carefully uprooted from pots, and plant shoot height, root length, and weight were measured. Severity of root galling on tomato plants was assessed on a $0-5$ rating scale according to the number of galls per plant, as follows: $0=$ none, $1=1-2,2=3-10,3=11-30,4=31-100$, and $5=>100$ galls (Taylor and Sasser, 1978). The nematode population was extracted from 100 -g subsamples of the soil samples and sieved through 30-mesh, 200-mesh, and 325mesh sieves, followed by the Baermann funnel procedure for $48 \mathrm{~h}$ (Southey, 1986). Recovered organisms including nematodes were preserved in triethanolamine-formalin (TAF) fixative at $80^{\circ} \mathrm{C}$, mounted on glass slides (Southey, 1986), and observed under a stereoscope microscope to enumerate the nematode populations. All trophic states, excluding second stage juveniles of $M$ incognita, were determined based on stoma and esophageal morphology, and combined and counted as non-parasitic nematodes.

Statistical analysis. For statistical analysis of the experi- 
mental results, analyses of variance were carried out using SAS version 4.2 (SAS Institute Inc., Cary, NC, USA), with Duncan's multiple range test (DMRT) to examine significant differences $(P \leq 0.05)$ among treatments. Correlation coefficients were computed to test significant correlations between physicochemical soil characters and their influence on plant growth, gall formation by the root-knot nematode, and populations of non-parasitic nematodes, at $P \leq 0.05$ and $P \leq 0.01$.

\section{Results}

Soil characteristics. The soil texture of all experimental sites was sandy loam, composed of 53.5-63.6\% sand, $2.6-4.6 \%$ clay, and $33.8-42.0 \%$ silt (data not shown). Other soil characters, except heavy metal content, are shown in Table 1. $\mathrm{pH}$ was lower in $\mathrm{CS}(\mathrm{pH} 2.5-2.8)$ than $\mathrm{NS}(\mathrm{pH}$ 4.1-4.6); EC was higher in CS (4.80-7.26 dS/m) than NS (0.39-0.46 dS/m); av. $\mathrm{P}_{2} \mathrm{O}_{5}$ was lower in $\mathrm{CS}(0.68-0.77 \mathrm{mg} /$ $\mathrm{kg}$ ) than NS (4.17-7.98 $\mathrm{mg} / \mathrm{kg})$; and nitrogen content [total nitrogen (T-N), $\mathrm{NO}_{3}^{-}-\mathrm{N}$, and $\mathrm{NH}_{4}{ }^{+}-\mathrm{N}$ ] and soluble cations $\left(\mathrm{K}^{+}, \mathrm{Ca}^{2+}, \mathrm{Mg}^{2+}, \mathrm{Na}^{+}\right)$were similar among the $\mathrm{CS}$ and $\mathrm{NS}$ soil samples, with no significant differences between $\mathrm{CS}$ and NS.

The content of As was remarkably higher in CS (especially CS-1 and CS-2: over 5,000 mg/kg) than in NS (Table 2). The $\mathrm{Cu}$ content was generally higher in $\mathrm{CS}$ than NS except for NS-3, which had the highest level; contents of $\mathrm{Cr}$, Ni, and $\mathrm{Zn}$ were somewhat higher in NS than $\mathrm{CS} ; \mathrm{Pb}$ was similar in CS and NS, except in NS-3 which had the highest level.

Plant growth and nematode development in soils from the abandoned mine. Growth of tomato plants (shoot height, shoot weight, root length, and root weight) was significantly lowered in CS compared to NS, with little or no significant difference within CS and NS samples. All plant growth parameters except root weight increased in

Table 1. Physicochemical characteristics of soil contaminated (CS: CS-1, CS-2 and CS-3) by drainage from an abandoned mine and of nearby uncontaminated soil (NS: NS-1, NS-2, and NS-3).

\begin{tabular}{lcccccc}
\hline \hline \multirow{2}{*}{ Soil characteristics } & \multicolumn{3}{c}{ CS } & \multicolumn{2}{c}{ NS } \\
\cline { 2 - 7 } & CS-1 & CS-2 & CS-3 & NS-1 & NS-2 & NS-3 \\
\hline $\mathrm{pH}(1: 5)$ & $2.5 \pm 0.14 \mathrm{c}^{\mathrm{a}}$ & $2.7 \pm 0.07 \mathrm{c}$ & $2.8 \pm 0.14 \mathrm{c}$ & $4.6 \pm 0.28 \mathrm{a}$ & $4.1 \pm 0.14 \mathrm{~b}$ & $4.1 \pm 0.14 \mathrm{~b}$ \\
$\mathrm{EC}(\mathrm{dS} / \mathrm{m})^{\mathrm{b}}$ & $7.26 \pm 0.23 \mathrm{a}$ & $7.42 \pm 0.18 \mathrm{a}$ & $4.8 \pm 0.14 \mathrm{~b}$ & $0.39 \pm 0.01 \mathrm{c}$ & $0.46 \pm 0.01 \mathrm{c}$ & $0.42 \pm 0.01 \mathrm{c}$ \\
$\mathrm{Total} \mathrm{N}(\mathrm{mg} / \mathrm{kg})$ & $400 \pm 141.4 \mathrm{a}$ & $400.0 \pm 141.4 \mathrm{a}$ & $300.0 \pm 77.8 \mathrm{a}$ & $700.0 \pm 212.1 \mathrm{a}$ & $400.0 \pm 0.0 \mathrm{a}$ & $500 \pm 141.4 \mathrm{a}$ \\
$\mathrm{NO}_{3}^{-}-\mathrm{N}(\mathrm{mg} / \mathrm{kg})$ & $0.22 \pm 0.01 \mathrm{~b}$ & $0.21 \pm 0.01 \mathrm{~b}$ & $0.2 \pm 0.01 \mathrm{~b}$ & $0.23 \pm 0.01 \mathrm{~b}$ & $0.41 \pm 0.16 \mathrm{a}$ & $0.31 \pm 0.08 \mathrm{ab}$ \\
$\mathrm{NH}_{4}{ }^{+}-\mathrm{N}(\mathrm{mg} / \mathrm{kg})$ & $1.25 \pm 0.06 \mathrm{ab}$ & $1.26 \pm 0.01 \mathrm{ab}$ & $1.25 \pm 0.01 \mathrm{ab}$ & $1.07 \pm 0.01 \mathrm{~b}$ & $1.35 \pm 0.14 \mathrm{a}$ & $1.17 \pm 0.16 \mathrm{ab}$ \\
$\mathrm{Av} . \mathrm{P}_{2} \mathrm{O}_{5}(\mathrm{mg} / \mathrm{kg})$ & $0.77 \pm 0.17 \mathrm{~d}$ & $0.69 \pm 0.00 \mathrm{~d}$ & $0.68 \pm 0.01 \mathrm{~d}$ & $4.17 \pm 0.01 \mathrm{c}$ & $7.98 \pm 0.03 \mathrm{a}$ & $6.47 \pm 0.04 \mathrm{~b}$ \\
$\mathrm{~K}[$ Ex. cation $(\mathrm{cmol} / \mathrm{kg})]$ & $0.12 \pm 0.00 \mathrm{a}$ & $0.11 \pm 0.03 \mathrm{a}$ & $0.12 \pm 0.01 \mathrm{a}$ & $0.12 \pm 0.00 \mathrm{a}$ & $0.11 \pm 0.01 \mathrm{a}$ & $0.11 \pm 0.03 \mathrm{a}$ \\
$\mathrm{Ca}[$ Ex. cation $(\mathrm{cmol} / \mathrm{kg})]$ & $0.32 \pm 0.01 \mathrm{abc}$ & $0.46 \pm 0.16 \mathrm{ab}$ & $0.49 \pm 0.15 \mathrm{c}$ & $0.43 \pm 0.01 \mathrm{abc}$ & $0.25 \pm 0.01 \mathrm{bc}$ & $0.22 \pm 0.01 \mathrm{c}$ \\
$\mathrm{Mg}[$ Ex. cation $(\mathrm{cmol} / \mathrm{kg})]$ & $0.32 \pm 0.00 \mathrm{bc}$ & $0.46 \pm 0.13 \mathrm{ab}$ & $0.49 \pm 0.02 \mathrm{a}$ & $0.43 \pm 0.03 \mathrm{ab}$ & $0.25 \pm 0.03 \mathrm{c}$ & $0.22 \pm 0.01 \mathrm{c}$ \\
$\mathrm{Na}[$ Ex. cation $(\mathrm{cmol} / \mathrm{kg})]$ & $0.12 \pm 0.01 \mathrm{a}$ & $0.11 \pm 0.00 \mathrm{a}$ & $0.12 \pm 0.00 \mathrm{a}$ & $0.12 \pm 0.01 \mathrm{a}$ & $0.11 \pm 0.00 \mathrm{a}$ & $0.11 \pm 0.00 \mathrm{a}$ \\
\hline
\end{tabular}

${ }^{a}$ Figures are averages and standard deviations of two replications. The same letters in a row denote no significant difference at $P \leq 0.05$ by Duncan's multiple range test (DMRT).

${ }^{b} \mathrm{EC}$ : electrical conductivity

Table 2. Heavy metal contents in soils contaminated with mine drainage (CS: CS-1, CS-2 and CS-3) and nearby non-contaminated soils (NS: NS-1, NS-2 and NS-3)

\begin{tabular}{ccccccc}
\hline \hline \multirow{2}{*}{ Heavy metal } & \multicolumn{5}{c}{ Heavy metal contents $(\mathrm{mg} / \mathrm{Kg})$} \\
\cline { 2 - 7 } & CS-1 & CS-2 & CS-3 & NS1- & NS-2 & NS-3 \\
\hline $\mathrm{As}$ & $5,510.0 \pm 193.3 \mathrm{a}^{\mathrm{a}}$ & $5,161.7 \pm 247.5 \mathrm{~b}$ & $2,552.3 \pm 13.7 \mathrm{c}$ & $36.7 \pm 1.9 \mathrm{e}$ & $40.1 \pm 1.1 \mathrm{e}$ & $380.0 \pm 14.6 \mathrm{~d}$ \\
$\mathrm{Cu}$ & $67.2 \pm 0.5 \mathrm{~d}$ & $158.1 \pm 1.8 \mathrm{~b}$ & $95.9 \pm 0.7 \mathrm{c}$ & $25.3 \pm 2.3 \mathrm{e}$ & $30.1 \pm 5.5 \mathrm{e}$ & $186.9 \pm 0.1 \mathrm{a}$ \\
$\mathrm{Cr}$ & $4.2 \pm 0.0 \mathrm{c}$ & $2.0 \pm 0.0 \mathrm{~d}$ & $4.4 \pm 0.2 \mathrm{c}$ & $11.5 \pm 0.3 \mathrm{~b}$ & $11.4 \pm 0.1 \mathrm{~b}$ & $18.4 \pm 0.1 \mathrm{a}$ \\
$\mathrm{Ni}$ & $1.2 \pm 0.1 \mathrm{c}$ & $0.2 \pm 0.1 \mathrm{~d}$ & $1.3 \pm 0.1 \mathrm{c}$ & $5.9 \pm 0.3 \mathrm{~b}$ & $5.6 \pm 0.3 \mathrm{~b}$ & $8.8 \pm 0.1 \mathrm{a}$ \\
$\mathrm{Pb}$ & $20.1 \pm 2.0 \mathrm{c}$ & $38.8 \pm 0.8 \mathrm{~b}$ & $30.4 \pm 0.3 \mathrm{c}$ & $27.5 \pm 0.8 \mathrm{c}$ & $31.9 \pm 2.7 \mathrm{c}$ & $178.8 \pm 15.4 \mathrm{a}$ \\
$\mathrm{Zn}$ & $45.4 \pm 0.3 \mathrm{c}$ & $46.1 \pm 0.2 \mathrm{c}$ & $47.0 \pm 0.4 \mathrm{c}$ & $62.5 \pm 2.7 \mathrm{~b}$ & $62.1 \pm 0.4 \mathrm{~b}$ & $118.3 \pm 1.7 \mathrm{a}$
\end{tabular}

${ }^{a}$ Figures are averages and standard deviations of two replications. The same letters in a column denote no significant difference at $P \leq 0.05$ by Duncan's multiple range test (DMRT). 
Table 3. Shoot and root growth of tomato plants grown in soil contaminated (CS: CS-1, CS-2 and CS-3) by drainage from an abandoned mine, nearby non-contaminated soil (NS: NS-1, NS-2, and NS-3), inoculated control (Control-A), and non-inoculated control (Control$\mathrm{B}$ ), and gall formation (index) on tomato plants inoculated with the root-knot nematode and non-parasitic nematode populations 8 weeks after inoculation.

\begin{tabular}{|c|c|c|c|c|c|c|c|}
\hline \multirow{2}{*}{ Soil $^{\mathrm{a}}$} & & \multicolumn{2}{|c|}{ Shoot } & \multicolumn{2}{|c|}{ Root } & \multirow{2}{*}{ Gall index ${ }^{b}$} & \multirow{2}{*}{$\begin{array}{l}\text { No. of non-parasitic } \\
\text { nematodes (/650 g soil) }\end{array}$} \\
\hline & & Height $(\mathrm{cm})$ & Weight (g) & Length $(\mathrm{cm})$ & Weight (g) & & \\
\hline \multirow{3}{*}{$\mathrm{CS}$} & CS-1 & $6.1 \pm 13.7 \mathrm{~d}^{\mathrm{c}}$ & $1.0 \pm 2.3 b$ & $0.9 \pm 1.9 \mathrm{c}$ & $0.3 \pm 0.7 \mathrm{c}$ & $0.2 \pm 0.4 \mathrm{c}$ & $251.2 \pm 74.0 \mathrm{de}$ \\
\hline & CS-2 & $20.2 \pm 22.1 \mathrm{~cd}$ & $3.4 \pm 4.0 \mathrm{~b}$ & $5.6 \pm 8.2 b c$ & $1.1 \pm 1.3 b c$ & $0.8 \pm 1.1 b c$ & $1,016.8 \pm 694.1 \mathrm{cde}$ \\
\hline & CS-3 & $32.3 \pm 24.4 b c$ & $6.4 \pm 5.6 b$ & $11.1 \pm 9.3 \mathrm{abc}$ & $2.9 \pm 2.7 \mathrm{abc}$ & $3.0 \pm 2.7 \mathrm{ab}$ & $1,542.0 \pm 473.1 \mathrm{~cd}$ \\
\hline \multirow{3}{*}{ NS } & NS-1 & $50.5 \pm 6.3 \mathrm{ab}$ & $9.9 \pm 4.4 b$ & $19.7 \pm 9.7 \mathrm{a}$ & $9.9 \pm 3.0 \mathrm{a}$ & $4.4 \pm 1.3 \mathrm{a}$ & $3,752.0 \pm 2,234.9 \mathrm{a}$ \\
\hline & NS-2 & $55.9 \pm 2.4 \mathrm{ab}$ & $11.1 \pm 4.2 \mathrm{~b}$ & $12.8 \pm 4.1 \mathrm{ab}$ & $10.0 \pm 7.4 \mathrm{ab}$ & $4.4 \pm 1.3 \mathrm{a}$ & $3,012 \pm 1,002.4 \mathrm{ab}$ \\
\hline & NS-3 & $49.3 \pm 6.8 \mathrm{ab}$ & $10.2 \pm 3.3 b$ & $12.4 \pm 5.2 \mathrm{abc}$ & $4.6 \pm 3.8 \mathrm{abc}$ & $4.2 \pm 1.1 \mathrm{a}$ & $2,075 \pm 886.5 b c$ \\
\hline \multicolumn{2}{|c|}{ Control-A } & $58.8 \pm 2.2 \mathrm{a}$ & $40.0 \pm 14.4 \mathrm{a}$ & $14.7 \pm 1.7 \mathrm{ab}$ & $12.7 \pm 5.4 \mathrm{ab}$ & $5.0 \pm 0.0 \mathrm{a}$ & $31.6 \pm 32.6 \mathrm{e}$ \\
\hline \multicolumn{2}{|c|}{ Control-B } & $56.1 \pm 9.2 \mathrm{ab}$ & $38.0 \pm 10.8 \mathrm{a}$ & $13.2 \pm 4.2 \mathrm{ab}$ & $4.1 \pm 2.2 \mathrm{ab}$ & $0.0 \pm 0.0 \mathrm{c}$ & $19.2 \pm 16.5 \mathrm{e}$ \\
\hline
\end{tabular}

${ }^{\mathrm{a}}$ Inoculated with 1,000 eggs of Meloidogyne incognita per pot containing $650 \mathrm{~g}$ soil, except Control-B (non- inoculation control)

${ }^{\mathrm{b}}$ Severity of root galling (gall index) on tomato plants: $0=$ no, $1=1-2,2=3-10,3=11-30,4=31-100$, and $5=>100$ galls (Taylor and Sasser, 1978)

${ }^{\circ}$ Figures are averages and standard deviations of five replications. The same letters in a column denote no significant difference at $P \leq 0.05$ by Duncan's multiple range test (DMRT).

Table 4. Correlation coefficients for soil characters and heavy metal content with plant growth, gall formation on tomato plants inoculated with Meloidogyne incognita, and non-parasitic nematode populations.

\begin{tabular}{|c|c|c|c|c|c|c|}
\hline \multirow{2}{*}{$\begin{array}{c}\text { Soil } \\
\text { characteristics }\end{array}$} & \multicolumn{2}{|c|}{ Shoot } & \multicolumn{2}{|c|}{ Root } & \multirow{2}{*}{$\begin{array}{l}\text { Gall } \\
\text { index }\end{array}$} & \multirow{2}{*}{$\begin{array}{c}\text { No. of non-parasitic } \\
\text { nematodes (/650 g soil) }\end{array}$} \\
\hline & Height & Weight & Length & Weight & & \\
\hline $\mathrm{pH}$ & $0.53^{* * a}$ & $0.43 * *$ & $0.37 * *$ & $0.47 * *$ & $0.50^{* *}$ & $0.51 * *$ \\
\hline $\mathrm{EC}$ & $-0.59 * *$ & $-0.48 * *$ & $-0.35^{* *}$ & $-0.44^{* *}$ & $-0.58 * *$ & $-0.46^{* *}$ \\
\hline T-N & $0.16^{*}$ & $0.12 \mathrm{NS}$ & $0.22 * *$ & $0.20 *$ & $0.15^{*}$ & $0.29 * *$ \\
\hline $\mathrm{NO}_{3}^{-}$ & $0.30^{* *}$ & $0.24 * *$ & $0.04 \mathrm{NS}$ & $0.23 * *$ & $0.22 * *$ & $0.13^{*}$ \\
\hline $\mathrm{NH}_{4}$ & $-0.02 \mathrm{NS}$ & $-0.02 \mathrm{NS}$ & $-0.13^{*}$ & $-0.02 \mathrm{NS}$ & $-0.05 \mathrm{NS}$ & $-0.09 \mathrm{NS}$ \\
\hline $\mathrm{P}_{2} \mathrm{O}_{5}$ & $0.47 * *$ & $0.38 * *$ & $0.16^{*}$ & $0.35^{* *}$ & $0.40 * *$ & $0.29 * *$ \\
\hline As & $-0.61^{* *}$ & $-0.50^{* *}$ & $-0.38 * *$ & $-0.45^{* *}$ & $-0.61 * *$ & $-0.48^{* *}$ \\
\hline $\mathrm{Cu}$ & $-0.02 \mathrm{NS}$ & $-0.02 \mathrm{NS}$ & $-0.04 \mathrm{NS}$ & $-0.19^{*}$ & $-0.03 \mathrm{NS}$ & $-0.12 \mathrm{NS}$ \\
\hline $\mathrm{Cr}$ & $0.39 * *$ & $0.34 * *$ & $0.18^{*}$ & $0.21 *$ & $0.39 * *$ & $0.22 * *$ \\
\hline $\mathrm{Ni}$ & $0.43^{* *}$ & $0.37 * *$ & $0.21 *$ & $0.26^{* *}$ & $0.42 * *$ & $0.27 * *$ \\
\hline $\mathrm{Pb}$ & $0.08 \mathrm{NS}$ & $0.08 \mathrm{NS}$ & $0.01 \mathrm{NS}$ & $0.00 \mathrm{NS}$ & $0.08 \mathrm{NS}$ & $0.00 \mathrm{NS}$ \\
\hline $\mathrm{Zn}$ & $0.21^{*}$ & $0.19^{*}$ & $0.07 \mathrm{NS}$ & $0.04 \mathrm{NS}$ & $0.20 *$ & $0.06 \mathrm{NS}$ \\
\hline
\end{tabular}

a $*$ : significant at $P \leq 0.05, * *$ : significant at $P \leq 0.01$, NS: not significant

control soils with or without nematode inoculation compared to the experimental soils; however, there were no significant differences in plant growth between control soils with nematode inoculation (Control-A) and without nematode inoculation (Control-B) (Table 3).

Gall formation on tomato roots, as a method to examine nematode development, was significantly lower in CS (except CS-3) than in NS and Control-A (Table 3). There was a significant difference in gall formation within $\mathrm{CS}$, which decreased more significantly in the order CS-1, CS-2, and CS-3. No significant difference was noted in gall formation in NS and Control-A.

Populations of non-parasitic nematodes were significant- ly lower in CS compared to NS, with a significant reduction in nematode populations in CS in the order CS-1, CS-2, and CS-3, which was similar to gall formation.

Correlation of soil characteristics with plant growth, gall formation, and non-parasitic nematode populations. Significant or highly significant correlations were found in plant growth, gall formation, and non-parasitic nematode populations in relation to the soil characters of $\mathrm{pH}, \mathrm{EC}$, $\mathrm{NO}_{3}{ }^{-}-\mathrm{N}$, av. $\mathrm{P}_{2} \mathrm{O}_{5}$, and content of the heavy metals As, Cr, $\mathrm{Ni}$, and $\mathrm{Zn}$ (Table 4). Most significant decreases in plant growth, gall formation, and non-parasitic nematode populations occurred in relation to As, followed by $\mathrm{pH}$ and $\mathrm{EC}$, 
with most correlation coefficients around 0.5. In addition, av. $\mathrm{P}_{2} \mathrm{O}_{5}$ had a relatively high correlation with all plant growth parameters and the nematode development.

\section{Discussion}

Growth of tomato plants (shoot height, shoot weight, root length, and root weight) was reduced greatly in CS with lower $\mathrm{pH}$, higher $\mathrm{EC}$, lower av. $\mathrm{P}_{2} \mathrm{O}_{5}$, and especially with high As compared to NS. The reduction in plant growth was highly correlated with the As content in the soils examined. In this study, the tomato plants grown in $\mathrm{CS}$, especially in CS-1 and CS-2 with As of over $5,000 \mathrm{mg} / \mathrm{kg}$, showed leaf yellowing and wilting 4 weeks after planting, similar to the symptoms of As toxicity found by Machlis (1941), who reported leaf wilting followed by root discoloration and leaf tip necrosis. Reduced growth was also reported for Arabidopsis thaliana cv. Columbia grown in culture media with a high content of $\mathrm{Pb}$ (Lee, 2010). In addition, $\mathrm{Zn}$ toxicity to crop plants was evident in fields contaminated with over $300 \mathrm{mg} / \mathrm{kg}$ of $\mathrm{Zn}$ from mining and smelting activities (Chaney, 1993; Marschner, 1995). However, apart from As, other heavy metals such as $\mathrm{Pb}$ and $\mathrm{Zn}$ were either higher in CS or in NS, with no remarkable differences between the two soils, and were correlated negatively or positively with plant growth, suggesting that these heavy metals had no critical effects on plant growth in our study.

Arsenic (As, atomic number: 33) is regarded as a heavy metal, despite being a semimetal (metalloid), according to the definition of heavy metals associated with contamination and potential toxicity or ecotoxicity (Duffus, 2002). It is a notorious toxin to many organisms, and has been used in pesticides, insecticides (probably toxic to nematodes), fungicides, and herbicides (Abernathy, 1983; Azcue and Nriagu, 1994). In our study, gall formation caused by the root-knot nematode was reduced significantly in tomato plants grown in CS (especially in CS-1 and CS-2 with high As content) compared to that in NS and the inoculated control (Control-A). In addition, the free-living nematode populations in the soil were significantly reduced in CS compared to NS. This result indicates that the reduction in gall formation may be due to direct heavy metal toxicity as an insecticide (nematicide) to second stage juveniles of the root-knot nematode, preventing nematode penetration into root tissues, and to third and fourth stage juveniles or adults inside root tissues, where they induce giant cells (and gall formation) through feeding (Moon et al., 2010). Heavy metals at high concentrations are known to have strong adverse effects on nematode communities in soils (Sánchez-Moreno and Navas, 2007) and accumulate in plant tissues at concentrations hazardous to human health
(Kim et al., 1998, 2002). Toxicity to nematodes may also be attributable to the inhibitory effect of As as an herbicide, reducing tomato root growth, consequently inhibiting the formation and development of giant cells related to the gall formation of the root-knot nematode (Son et al., 2009). In our study, the reduction in nematode populations was not as large as the reduction in gall formation, suggesting that the nematicidal activity of As may be lower than its phytotoxic (herbicidal) activity. In this respect, the use of As as a nematicide is not recommended because of its high phytotoxicity.

Correlation coefficients for soil characteristics with plant growth, gall formation, and nematode populations also showed that soil $\mathrm{pH}, \mathrm{EC}$, and possibly av. $\mathrm{P}_{2} \mathrm{O}_{5}$ were nearly the same $(P \leq 0.01)$ as those with As. The chemical forms of heavy metals in soil and their uptake rates by plants are affected by soil $\mathrm{pH}$, resulting in an increase in exchangeable forms of heavy metals at low $\mathrm{pH}$, as low soil $\mathrm{pH}$ results in a concomitant increase in exchangeable forms of $\mathrm{Cd}, \mathrm{Zn}$, and $\mathrm{Pb}$ (Xian and Shokohifard, 1989). A reduction in av. $\mathrm{P}_{2} \mathrm{O}_{5}$ in $\mathrm{CS}$ can also be explained by its precipitation in heavy metal-contaminated acid soils because av. $\mathrm{P}_{2} \mathrm{O}_{5}$ precipitates with coexisting $\mathrm{Al}$ and $\mathrm{Fe}$ hydrolytic metal species, which also decrease soil pH (Ro and Cho, 2000). At the same time, reduced soil $\mathrm{pH}$ also results in a concomitant increase in exchangeable cations. In this sense, lower $\mathrm{pH}$ in $\mathrm{CS}$ than in NS may enhance the toxicity of As and other heavy metals such as $\mathrm{Cu}$ whose content was not even lower in CS than in NS. Soil EC, a measure of soil salinity, adversely affects plant growth through decreased osmotic potential (i.e., increased osmotic pressure) and/or the specific effects of individual ions that contribute to soil salinity (Bernstein, 1975). In our study, there were no remarkable differences in the ions examined, except the heavy metal As, that would account for the difference in EC between CS and NS, suggesting that As and other heavy metals that ionized at lower $\mathrm{pH}$ (especially $\mathrm{Cu}$ ) in $\mathrm{CS}$ may have increased $\mathrm{EC}$ and thus adversely affected plant growth and root-knot nematode development. In conclusion, the effects of soil contamination by drainage from an abandoned mine in our study were derived primarily from contamination by heavy metals (especially As). This contamination led to enhanced toxicity (solubility) by the lowered $\mathrm{pH}$, and to increased soil salinity and decreased av. $\mathrm{P}_{2} \mathrm{O}_{5}$, thus having synergistic adverse effects on plant growth by decreasing osmotic potential and increasing nutrient deprivation.

\section{References}

Abernathy, J. R. 1983. Role of arsenical chemicals in agriculture. In: Arsenic: Industrial, Biomedical, Environmental Perspectives, ed. by W. H. Lederer and R. J. Fensterheim, pp. 57-60. 
Van Norstrand Reinhold, New York, USA.

Adriano, D. C. 1986. Trace Elements in the Terrestrial Environment. Springer, NY. 790 pp.

Azcue, J. M. and Nriagu, J. O. 1994. Arsenic: Historical perspectives. In: Arsenic in the Environment, Part 1: Cycling and Characterization, ed. by J. O. Nriagu, pp. 1-16. John Wiley \& Sons, NY, USA.

Beare, M. H. 1997. Fungal and bacterial pathway of organic matter decomposition and nitrogen mineralization in arable soil. In: Soil Ecology in Sustainable Agricultural Systems, ed. by L. Brussaard and R. Ferrera-Cerrato, pp. 37-70. Lewis. Boca Raton, FL. U.S.A.

Bernstein, L. 1975. Effects of salinity and sodicity on plant growth. Annu. Rev. Phytopathol. 13:295-312.

Chaney, R. L. 1993. Zinc phytotoxicity. In: Zinc in Soil and Plants, ed. by A. D. Robson, pp. 135-150. Kluwer Academic Publishers, Dordrecht, the Netherlands.

Doran, J. W., Sarrantonio, M. and Liebig, M. A. 1996. Soil health and sustainability. Adv. Agron. 56:1-54.

Duffs, J. H. 2002. "Heavy metals"- a meaningless term?. Pure Appl. Chem. 74:793-807.

Ferris, H., Venette, R. C., van der Meulen, H. R. and Lau, S. S. 1998. Nitrogen mineralization by bacteria-feeding nematodes: Verification and measurement. Plant Soil 203:159-171.

Holmgren, G. G. S., Meyer, M. W., Chaney, R. L. and Daniels, R. B. 1993. Cadmium, lead, zinc, copper and nickel in agricultural soils of the United States of America. J. Environ. Qual. 22:335-348.

Ingham, R. E., Trofymow, J. A., Inham, E. R. and Coleman, D. C. 1985. Interactions of bacteria, fungi, and their nematode grazers: Effects on nutrient cycling and plant growth. Ecol. Monogr. 55:119-140.

Kim, M. H., Song, S. H., Min, E. S. and Jang, I. S. 1998. Alkali and metal element concentrations in soil and plant from Daesung Coal Mine in Keumsan, Chungnam. Kor. J. Ecol. 21: 457-463.

Kim, M. H., Sho, Y. S., Kim, E. J., Chung, S. Y. and Hong, M. K. 2002. Studies on heavy metal contamination of agricultural products, soil and irrigation waters in abandoned mines. $J$. Fd. Hyg. Safety 17:178-182.

Klute, A. 1986. Methods of Soil Analysis. 2nd ed. American Society of Agronomy, Madison, WI, USA. 1188pp.

Lee, S. M. 2010. Effect of various biodegradable chelating agents on growth of plants under lead stress. Korean J. Environ. Agric. 28:61-65.

Machlis, L. 1941. Accumulation of arsenic in the shoots of Sudan grass and bush beans. Plant Physiol. 16:521-544.

Marschner, H. 1995. Mineral Nutrition of Higher Plants, 2nd ed. Academic Press, London, UK. 889pp.

McBride, M. B. 1994. Environmental Chemistry of Soils. Oxford University Press, NY, USA. 395 pp.
Mhatre, G. N. and Pankhurst, C. E. 1997. Bioindicators to detect contamination of soils with special reference to heavy metals. In Biological Indicators of Soil Health, ed. by C. Pankhurst, B. M. Doube and V. V. S. R. Gupta, pp. 349-369. CAB International, UK.

MOE. 2005. Soil Environment Conservation Act. Ministry of Environment, Korea.

Moon, H. S., Khan, Z., Kim, S. G. and Kim, Y. H. 2010. Biological and structural mechanisms of disease development and resistance in chili pepper infected with the root-knot nematode. Plant Pathol. J. 26:149-153.

Neher, D. 2001. Role of nematodes in soil health and their use as indicators. J. Nematol. 33:161-168.

NIAST. 2000. Methods of Soil and Plant Analysis. National Institute of Agricultural Science and Technology, Suwon, Korea. 202 pp.

Park, B. Y. 2011. Effects of heavy metal contamination on soil nematode community structure in an agricultural ecosystem. Ph.D. thesis. Seoul National University, Seoul, Korea.

Rajkumar, M., Nagendran, R., Lee, K. J., Lee, W. H. and Kim, S. Z. 2005. Influence of plant growth promoting bacteria and $\mathrm{Cr}^{6+}$ on the growth of Indian mustard. Chemosphere 62:741-748.

Ro, H. M. and Cho, C. M. 2000. Diffusive phosphate transport in Al-rich acidic porous cation exchange system. Can. J. Soil Sci. 80:551-560.

Sánchez-Moreno, S. and Navas, A. 2007. Nematode diversity and food web condition in heavy metal polluted soils in a river basin in southern Spain. Eur. J. Soil. Biol. 43:166-179.

Seo, K. W., Son, Y. H., Kim, R. H., Koo, J. W., Noh, N. J., Kyung, J. H. and Kim, J. G. 2006. Vegetation distribution near abandoned metalliferous mines and seed germination properties of woody plants by the contaminated soils. Kor. J. Environ. Agric. 25:47-57.

Son, S. H., Khan, Z., Kim, S. G. and Kim, Y. H. 2009. Plant growth-promoting rhizobacteria, Paenibacillus polymyxa and Paenibacillus lentimorbus suppress disease complex caused by root-knot nematode and fusarium wilt fungus. J. Appl. Microbiol. 107:524-532.

Southey, J. F. 1986. Laboratory Methods for Work with Plant and Soil nematodes. Her Majesty's Stationery Office, London, UK. 202 pp.

Taylor, A. L. and Sasser, J. N. 1978. Biology, Identification, and Control of Root-knot Nematodes (Meloidogyne species). North Carolina State University Graphics, Raleigh, NC. USA. $111 \mathrm{pp}$

Vulava, V. M., James, B. R. and Torrents, A. 1997. Copper solubility in Myersville B horizon soil in the presence of DTPA. Soil Sci. Soc. Am. J. 61:44-52.

Xian, X. and Shokohifard, G. I. 1989. Effect of $\mathrm{pH}$ on chemical forms and plant availability of cadmium, zinc, and lead in polluted soils. Water Air Soil Pollut. 45:265-273. 